\title{
Occupational mortality of women aged $15-59$ years at death in England and Wales
}

\author{
Kath A Moser, Peter O Goldblatt
}

\begin{abstract}
Study objective-The aim was to analyse occupational mortality differences among women using follow up data from a large nationally representative sample.

Design-Occupational information was obtained from the 1971 census records of women in the Longitudinal Study carried out by the Office of Population Censuses and Surveys (OPCS) and related to their subsequent mortality in the period between the 1971 and 1981 censuses.
\end{abstract}

Setting-In the Longitudinal Study, census, vital statistics, and other OPCS records are linked for a $1 \%$ sample of the population of England and Wales. The women studied in this paper were drawn from the 513071 persons in the 1971 census who were included in the Longitudinal Study and whose entries were traced at the National Health Service Central Register by 1977.

Participants-The analysis was based on 77081 women aged 15-59 years in the Longitudinal Study for whom occupational information was collected in the 1971 census ( $99 \%$ of whom were in paid employment in the week before the census). There were 1553 deaths among these women in the follow up period analysed here.

Measurements and main resultsNumbers of deaths in each occupational group at census were compared to those expected on the basis of age specific death rates among all women in the study. "Professional, technical workers, and artists" had significantly low mortality while "Engineering and allied trades workers nec" had significantly high mortality. Among the latter, cancer mortality of electrical production process workers was extremely high. A number of other cause specific associations (which appear to confirm proportionate Decennial Supplement analyses) were suggested by the data; examples include high levels of mortality from ischaemic heart disease among cooks, lung cancer and respiratory disease among charwomen and cleaners, and accidents, poisonings, and violence among several groups of professional and technical workers.

Conclusions-By using prospective follow up from the census, occupational differences in mortality can be identified among women in paid employment. As follow up of this study continues, numbers of deaths available for analysis will increase, allowing increasingly comprehensive analyses to be undertaken.

Most studies of occupational mortality in England and Wales, whether at a national level or on more narrowly defined populations, have concentrated on men. Comparatively little is known about the mortality of the female working population, especially in relation to particular occupations.

A few prospective studies have looked at the mortality of specific occupational groups of women, for example, gas mask assemblers ${ }^{1}$ and asbestos workers. ${ }^{2}$ In some industries women, if included in the study, are too few in number to provide useful results ${ }^{3}$ but, conversely, there are occupations in which women constitute a large proportion of the work force (for example, textile workers ${ }^{4}$ ).

Routine mortality statistics have been used to investigate women's occupational mortality. However, the practice has been to present data on single women by their own occupation ${ }^{5}$ and married women by their husbands' occupations. ${ }^{6}$ This approach has been severely criticised. ${ }^{7-9}$ Roman et $a l^{10}{ }^{11}$ analysed the death registration data around the 1971 census using the women's own occupation and proportional mortality ratios by cause of death.

The lack of information on women's occupational mortality is due, in part, to limitations of the data recorded at death registration. Instructions supplied to Registrars concerning occupational reporting at death of married women emphasise the recording of husband's occupation. ${ }^{6}$ Only for those in full time work at death is any attempt made to record their own occupation; part time, or previous full time, occupation is disregarded. Hence, only $20^{\circ}{ }_{0}$ of the deaths in 1970-72 to women aged 15-64 had own occupation recorded; this proportion was much lower among married and widowed women $(10 \%$ and $12 \%$, respectively). In contrast, the proportion with an occupation recorded at census was considerably higher; housewives were the most substantial group excluded. While these differences in recording practice lead to numerator-denominator biases in cross sectional studies, ${ }^{6}$ they do not affect prospective analyses. Several mortality studies have previously been undertaken which used census records as a source of occupational data; ${ }^{12-14}$ however only one of these includes satisfactory data on women.

In this paper we analyse data from the Longitudinal Study carried out by the Office of Population Censuses and Surveys (OPCS), which includes mortality follow up of a $1^{\circ}{ }_{0}$ sample of the 1971 census and is therefore suitable for examining a range of occupations. 


\section{Methods}

The Longitudinal Survey links information from individual census and vital event records for a $1 \%$ sample of the population of England and Wales. Further details concerning the Longitudinal Study and the methodology used to analyse mortality in the study are described elsewhere. ${ }^{15}$ Here we look at mortality among women aged 15-59 years in the period $1971-81$ and relate this to their occupation as recorded in the 1971 census. Questions on occupation were asked "in respect of the main employment last week, or of the most recent job if retired or out of work." Housewives who did not have a job in the previous week were not required to answer. The analysis presented here is limited to those women for whom occupational information was collected (most of whom were in employment at census). Occupations were classified according to the 1970 Classification of Occupations. ${ }^{16}$ Where appropriate we also consider whether the women were working full or part time (with the latter defined as working $30 \mathrm{~h}$ or less a week, in line with the definition used in many official surveys ${ }^{17}$ ).

All cause mortality is examined for each occupation order and for a number of occupation units. For the larger orders and units (and those with significantly high all cause mortality), we consider cause specific mortality for the four main ICD chapter headings and, where the numbers permit, stomach, lung, and breast cancers, ischaemic heart disease, and cerebrovascular disease (8th Revision ICD codes). Standardised mortality ratios (SMRs) are used as summary indices of mortality; 95\% confidence intervals (CIs) are also presented. ${ }^{18}$ The death rates used for standardisation are those for all women in the Longitudinal Study. However, women with an occupation recorded tend to be a healthy subgroup, as they exclude those prevented by illness from working at the time of the census. ${ }^{19}$ Consequently, in presenting results, the mortality of each occupational group is compared to that of all women classified to an occupation.

\section{Results}

POPULATION COVERED

Of women aged $15-59$ years in $1971,53 \%$ could be classified to an occupation; a further $44 \%$ were classified as "unoccupied" (predominantly housewives but also students and those classified as permanently sick or disabled) and 3\% were classified as having "inadequately described occupations" (economically active, but with insufficient information to enable them to be classified to an occupation) (fig 1). The proportion with occupational information recorded varied considerably with age and marital status. It was particularly low for those aged 25-34 years and among married women.

The 1970 Classification of Occupations identified 220 units which were aggregated into 25 occupation orders (excluding the armed forces and inadequately described occupations). Of the 77081 women aged 15-59 in the Longitudinal Study in 1971 who could be classified to an occupation, $75 \%$ were included in just four occupation orders. These were clerical workers (Order XXI), who constituted $30 \%$ of women with an occupation; service, sport, and recreation workers (Order XXIII, comprising $22 \%$ ); professional, technical workers, and artists (Order XXV, comprising 12\%); and sales workers (Order XXII, comprising $12 \%$ ). None of the other orders contained more than $4 \%$ of women classified to an occupation and most contained considerably less (fig 1).

Many occupation orders were very heterogeneous, containing occupations spanning a wide range of skills, types of exposure to hazards, and patterns of work. For example, Order XXIII (service, sport, and recreation workers) included, among others, police officers, persons owning or managing boarding houses or hotels, housekeepers, waitresses, cooks, canteen assistants, charwomen, office cleaners, hairdressers, launderers, and hospital orderlies.

The 220 occupation units offer a finer differentiation between jobs. Nonetheless this greater specificity is, in several respects, more apparent than real since half the women who could be classified to an occupation were in just six units. These were clerks and cashiers (Unit 139) containing $18 \%$ of women with an occupation; typists, shorthand writers, and secretaries (Unit 141, comprising 10\%); shop sales workers and assistants (Unit 144; comprising $9 \%$ ); nurses (Unit 183, comprising $5 \%$ ); and charwomen, office cleaners etc (Unit 166) and maids, valets, and related service workers (Unit 164), each of which contained $4 \%$ of women with an occupation (fig 1). A further $17 \%$ were accounted for by the six next largest units: primary and secondary school teachers (Unit 193), canteen assistants (Unit 161), sewing and embroidery workers (Unit 76), packers and labellers (Unit 137), sales managers and proprietors (Unit 143), and office machine operators (Unit 140).

The age structures of occupation units varied considerably. While two thirds of all women aged 15-59 years who had an occupation were below 45 years old, for several units this figure exceeded $80 \%$ (office machine operators and typists, shorthand writers and secretaries). Conversely, a number of units contained mainly older women (cooks, charwomen and office cleaners, maids, canteen assistants, and sales managers and proprietors, each with between $50 \%$ and $60 \%$ aged 45-59 years).

In 1971 nearly $40 \%$ of women in paid employment were working part time. The proportion varied considerably with age, marital status, and occupation. Only $8 \%$ of single women worked part time, but the figure for married women was $49 \%$. Occupations with a particularly high proportion of part time workers were charwomen and office cleaners $(89 \%)$, maids, and canteen assistants (both $69 \%$ ). Conversely full time work predominated among office machine operators, sales managers and proprietors, typists and secretaries, clerks and cashiers, sewing and embroidery workers, cooks, and nurses (in each of which units over three quarters worked full time).

\section{MORTALITY}

Women classified to an occupation had low mortality at ages 15-59 years in 1971-81. Their mortality was particularly low in $1971(\mathrm{SMR}=67$, 


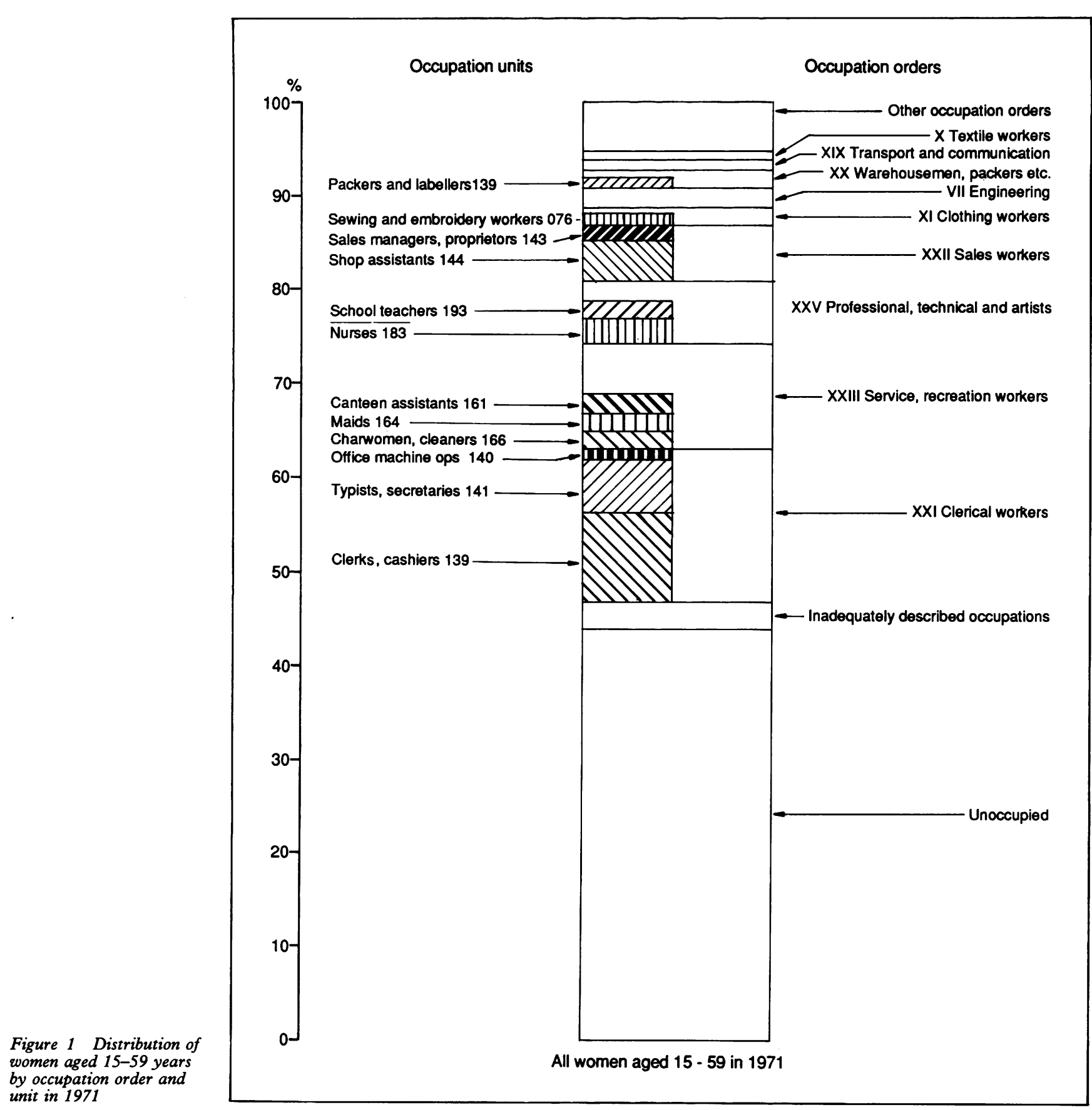

95\% CI 53-82) and rose with length of follow up to an $S M R=90$ for the period 1976-81 (fig 2). This effect of initial health selection, ${ }^{18}$ although evident throughout the age range, was particularly marked in the 45-59 year age group ( $S M R=81$ in $1971-75$ and 88 in 1976-81).

Mortality by occupation order in 1971-75 and $1976-81$ is summarised in table I. Since women classified to an occupation were a select, healthy group at census, their SMRs in these two time periods ( 83 and 90 , respectively) provide the appropriate reference points for the mortality of specific occupation orders. As indicated earlier differences from these values are assessed here using $95 \%$ confidence intervals around the SMRs for each order. It is evident, from this table, that there was considerable variation in the magnitude of changes in mortality over time as a result of health selection. In general, there was a greater tendency for the mortality of those in manual

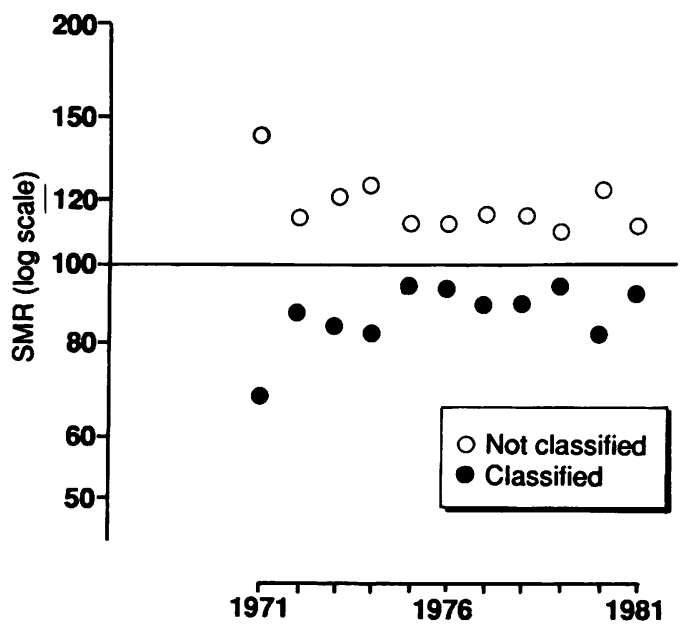

Figure 2 Mortality of women aged 15-59 years according to whether or not they were classified to an occupation, by year of death 
Table I Mortality of women aged 15-59 years by occupation order. Figures in parentheses are the numbers of observed deaths.

\begin{tabular}{|c|c|c|c|c|c|c|c|}
\hline \multirow{2}{*}{\multicolumn{2}{|c|}{ Occupation order }} & \multicolumn{3}{|c|}{$1971-75$} & \multicolumn{3}{|c|}{$1976-81$} \\
\hline & & \multirow[b]{2}{*}{$\begin{array}{c}S M R \\
94 \\
25 \\
96 \\
141 \\
99 \\
81 \\
96\end{array}$} & \multirow[b]{2}{*}{$\begin{array}{l}(O b s) \\
(10) \\
(1) \\
(10) \\
(52) \\
(6) \\
(14) \\
(29)\end{array}$} & \multirow[b]{2}{*}{$\begin{array}{r}95 \% C I \\
45-172 \\
0-140 \\
46-177 \\
106-185 \\
36-216 \\
44-135 \\
64-138\end{array}$} & \multirow[b]{2}{*}{$\begin{array}{r}S M R \\
73 \\
81 \\
92 \\
129 \\
98 \\
127 \\
85\end{array}$} & \multirow[b]{2}{*}{$\begin{array}{l}(\text { Obs }) \\
(8) \\
(3) \\
(10) \\
(47) \\
(6) \\
(20) \\
(24)\end{array}$} & \multirow[b]{2}{*}{$\begin{array}{l}95^{\circ}{ }_{\circ} C I \\
31-144 \\
17-238 \\
44-168 \\
95-171 \\
36-213 \\
77-196 \\
54-126\end{array}$} \\
\hline $\begin{array}{l}\text { I } \\
\text { IV } \\
\text { VI } \\
\text { VII } \\
\text { IX } \\
\text { X } \\
\text { XI }\end{array}$ & $\begin{array}{l}\text { Farmers, foresters, fisherwomen } \\
\text { Glass and ceramic makers } \\
\text { Electrical and electronic workers } \\
\text { Engineering and allied trades workers nec } \\
\text { Leather workers } \\
\text { Textile workers } \\
\text { Clothing workers }\end{array}$ & & & & & & \\
\hline $\begin{array}{l}\text { XII } \\
\text { XIII } \\
\text { XIV } \\
\text { XVII } \\
\text { XIX } \\
\text { XX }\end{array}$ & $\begin{array}{l}\text { Food, drink and tobacco workers } \\
\text { Paper and printing workers } \\
\text { Makers of other products } \\
\text { Labourers nec } \\
\text { Transport and communications workers } \\
\text { Warehouseworkers, storekeepers, packers, bottlers }\end{array}$ & $\begin{array}{r}35 \\
72 \\
135 \\
74 \\
64 \\
98\end{array}$ & $\begin{array}{l}(4) \\
(7) \\
(17) \\
(10) \\
(10) \\
(35)\end{array}$ & $\begin{array}{l}10-90 \\
29-149 \\
79-217 \\
35-136 \\
31-117 \\
68-136\end{array}$ & $\begin{array}{r}72 \\
129 \\
87 \\
96 \\
92 \\
113\end{array}$ & $\begin{array}{l}(8) \\
(12) \\
(11) \\
(12) \\
(15) \\
(38)\end{array}$ & $\begin{array}{l}31-141 \\
67-225 \\
44-157 \\
50-168 \\
52-152 \\
80-156\end{array}$ \\
\hline $\begin{array}{l}\text { XXI } \\
\text { XXXII } \\
\text { XXIII } \\
\text { XXIV } \\
\text { XXV }\end{array}$ & $\begin{array}{l}\text { Clerical workers } \\
\text { Sales workers } \\
\text { Service, sport, and recreation workers } \\
\text { Administrators and managers } \\
\text { Professional, technical workers, artists }\end{array}$ & $\begin{array}{l}76 \\
77 \\
82 \\
40 \\
90\end{array}$ & $\begin{array}{r}(166) \\
(90) \\
(203) \\
(4) \\
(87)\end{array}$ & $\begin{array}{l}65-89 \\
62-95 \\
71-94 \\
11-102 \\
72-112\end{array}$ & $\begin{array}{r}79 \\
86 \\
101 \\
70 \\
69\end{array}$ & $\begin{array}{r}(180) \\
(96) \\
(224) \\
(7) \\
(68)\end{array}$ & $\begin{array}{l}68-91 \\
70-105 \\
88-115 \\
28-145 \\
54-88\end{array}$ \\
\hline $\mathrm{I}-\mathrm{XXV}$ & & 83 & (759) & 78-90 & 90 & (794) & $84-96$ \\
\hline
\end{tabular}

SMR = Standardised mortality ratios; $\mathrm{CI}=$ confidence interval.

The standard population used in calculating the expected deaths was all women in the Longitudinal Study. Occupation orders with less than five expected deaths to women aged 15-59 years in the period 1971-81 were excluded from the table.

occupations to rise over time than was the case for those in non-manual occupations. For this reason, in order to compare mortality by occupation during a relatively stable period, we focus subsequently on mortality in 1976-81. In this period, only in the case of Orders VII (engineering and allied trades workers nec) and XXV (professional, technical workers, artists) was there strong evidence that mortality differed from that of all women with an occupation. While the former had a significantly high level of mortality $(S M R=129)$, the latter had a significantly low level $(S M R=69)$.

\section{MORTALITY OF MAJOR OCCUPATION ORDERS}

As indicated earlier, data for women classified to an occupation were dominated by the four largest occupation orders. Differences in mortality by cause of death in the period 1976-81 for these orders and their main component units are shown in table II.

While professional, technical workers and artists (Order XXV) had the lowest overall level of mortality, levels were also low for clerical workers (Order XXI) (SMR = 79) although, unlike Order $\mathrm{XXV}$, the confidence interval just failed to exclude 90 . The fact that the all cause SMR for all women with an occupation was below 100 was largely due to these occupation orders. Service, sport, and recreation workers (Order XXIII) had raised mortality, although the confidence interval again encompassed 90 .

ORDER XXV: PROFESSIONAL, TECHNICAL WORKERS, ARTISTS

The mortality of women in Order XXV was particularly low for circulatory diseases (SMR $=43,95 \%$ CI 22-75). This was mainly

Table II Mortality 1976-81 of women aged 15-59 years by occupation and cause of death: major Orders and their component Units. Figures in parentheses are the numbers of observed deaths.

\begin{tabular}{|c|c|c|c|c|c|c|c|c|c|c|c|c|c|c|c|}
\hline \multirow{3}{*}{\multicolumn{2}{|c|}{ Occupation order }} & \multicolumn{14}{|c|}{ Cause of death } \\
\hline & & \multirow{2}{*}{\multicolumn{2}{|c|}{ All causes }} & \multicolumn{4}{|c|}{$\begin{array}{l}\text { Malignant } \\
\text { neoplasms }\end{array}$} & \multicolumn{4}{|c|}{$\begin{array}{l}\text { Circulatory } \\
\text { diseases }\end{array}$} & \multicolumn{2}{|c|}{$\begin{array}{l}\text { Respiratory } \\
\text { diseases }\end{array}$} & \multicolumn{2}{|c|}{$\begin{array}{l}\text { Accidents and } \\
\text { violence }\end{array}$} \\
\hline & & & & \multicolumn{2}{|l|}{ All } & \multicolumn{2}{|l|}{ Breast } & \multicolumn{2}{|l|}{ All } & \multicolumn{2}{|l|}{$I H D$} & \multirow[b]{2}{*}{$S M R$} & \multirow[b]{2}{*}{ (Obs) } & \multirow[b]{2}{*}{$S M R$} & \multirow[b]{2}{*}{ (Obs) } \\
\hline & Occupation Unit & $S M R$ & (Obs) & $S M R$ & (Obs) & $S M R$ & (Obs) & $S M R$ & (Obs) & $S M R$ & (Obs) & & & & \\
\hline \multirow[t]{2}{*}{$\mathrm{XXI}$} & $\begin{array}{l}\text { Clerical workers } \\
\text { 139-Clerks, cashiers } \\
\text { 141-Typists, shorthand writers, } \\
\text { secretaries }\end{array}$ & $\begin{array}{l}79 \\
80 \\
68\end{array}$ & $\begin{array}{r}(180) \\
(120) \\
(44)\end{array}$ & $\begin{array}{l}92 \\
93 \\
82\end{array}$ & $\begin{array}{l}(96) \\
(64) \\
(24)\end{array}$ & $\begin{array}{r}116 \\
139 \\
66\end{array}$ & $\begin{array}{r}(37) \\
(29) \\
(6)\end{array}$ & $\begin{array}{l}62 \\
66 \\
40\end{array}$ & $\begin{array}{r}(40) \\
(29) \\
(7)\end{array}$ & $\begin{array}{l}59 \\
67 \\
25\end{array}$ & $\begin{array}{r}(18) \\
(14) \\
(2)\end{array}$ & $\begin{array}{r}33 \\
51 \\
-\end{array}$ & $\begin{array}{l}(5) \\
(5) \\
(-)\end{array}$ & $\begin{array}{l}92 \\
90 \\
97\end{array}$ & $\begin{array}{r}(15) \\
(9) \\
(5)\end{array}$ \\
\hline & Other clerical workers & 116 & (16) & 131 & (8) & 111 & (2) & 108 & (4) & 125 & (2) & - & $(-)$ & 77 & (1) \\
\hline XXII & $\begin{array}{l}\text { Sales workers } \\
\text { 143-Proprietors and managers, sales } \\
\text { 144-Shopsaleswomen and assistants } \\
\text { Other sales workers }\end{array}$ & $\begin{array}{r}86 \\
104 \\
77 \\
119\end{array}$ & $\begin{array}{r}(96) \\
(28) \\
(61) \\
(7)\end{array}$ & $\begin{array}{r}81 \\
95 \\
74 \\
111\end{array}$ & $\begin{array}{r}(42) \\
(12) \\
(27) \\
(3)\end{array}$ & $\begin{array}{r}83 \\
129 \\
73 \\
-\end{array}$ & $\begin{array}{r}(13) \\
(5) \\
(8) \\
(-)\end{array}$ & $\begin{array}{r}90 \\
84 \\
81 \\
235\end{array}$ & $\begin{array}{r}(30) \\
(7) \\
(19) \\
(4)\end{array}$ & $\begin{array}{r}92 \\
73 \\
79 \\
375\end{array}$ & $\begin{array}{r}(15) \\
(3) \\
(9) \\
(3)\end{array}$ & $\begin{array}{r}70 \\
119 \\
59 \\
-\end{array}$ & $\begin{array}{l}(5) \\
(2) \\
(3) \\
(-)\end{array}$ & $\begin{array}{r}91 \\
72 \\
103 \\
-\end{array}$ & $\begin{array}{l}(6) \\
(1) \\
(5) \\
(-)\end{array}$ \\
\hline \multirow[t]{3}{*}{ XXIII } & $\begin{array}{l}\text { Service, sport and recreation workers } \\
161 \text {-Canteen assistants, counter hands } \\
162-\text { Cooks } \\
\text { 164-Maids, valets and related service } \\
\text { workers }\end{array}$ & $\begin{array}{r}101 \\
99 \\
92 \\
107\end{array}$ & $\begin{array}{r}(224) \\
(40) \\
(13) \\
(49)\end{array}$ & $\begin{array}{r}116 \\
126 \\
60 \\
131\end{array}$ & $\begin{array}{r}(121) \\
(24) \\
(4) \\
(28)\end{array}$ & $\begin{array}{r}101 \\
68 \\
153 \\
139\end{array}$ & $\begin{array}{r}(32) \\
(4) \\
(3) \\
(9)\end{array}$ & $\begin{array}{r}84 \\
65 \\
180 \\
78\end{array}$ & $\begin{array}{r}(57) \\
(8) \\
(8) \\
(11)\end{array}$ & $\begin{array}{l}102 \\
115 \\
360^{\star} \\
29\end{array}$ & $\begin{array}{r}(34) \\
(7) \\
(8) \\
(2)\end{array}$ & $\begin{array}{r}122 \\
79 \\
114 \\
177\end{array}$ & $\begin{array}{r}(17) \\
(2) \\
(1) \\
(5)\end{array}$ & $\begin{array}{r}50 \\
100 \\
\overline{4}\end{array}$ & $\begin{array}{l}(6) \\
(2) \\
(-) \\
(1)\end{array}$ \\
\hline & $\begin{array}{l}\text { 166-Charwomen, office cleaners, window } \\
\text { cleaners }\end{array}$ & 112 & $(54)$ & 124 & (28) & 72 & (5) & 107 & (16) & 135 & (10) & 168 & (5) & 42 & (1) \\
\hline & $\begin{array}{l}\text { Other service, sport and recreation } \\
\text { workers }\end{array}$ & 91 & $(68)$ & 107 & (37) & 105 & (11) & 63 & (14) & 65 & (7) & 85 & (4) & 44 & (2) \\
\hline $\mathrm{XXV}$ & $\begin{array}{l}\text { Professional, technical workers, artists } \\
\text { 183-Nurses } \\
\text { 193-Primary and secondary teachers } \\
\text { Other professional, technical workers, } \\
\text { artists }\end{array}$ & $\begin{array}{l}69^{\star} \\
80 \\
54^{\star} \\
72\end{array}$ & $\begin{array}{l}(68) \\
(29) \\
(16) \\
(23)\end{array}$ & $\begin{array}{r}84 \\
101 \\
72 \\
75\end{array}$ & $\begin{array}{l}(38) \\
(17) \\
(10) \\
(11)\end{array}$ & $\begin{array}{r}98 \\
76 \\
90 \\
133\end{array}$ & $\begin{array}{r}(14) \\
(4) \\
(4) \\
(6)\end{array}$ & $\begin{array}{l}43^{\star} \\
39 \\
48 \\
43\end{array}$ & $\begin{array}{r}(12) \\
(4) \\
(4) \\
(4)\end{array}$ & $\begin{array}{c}15^{\star} \\
41 \\
- \\
-\star\end{array}$ & $\begin{array}{l}(2) \\
(2) \\
(-) \\
(-)\end{array}$ & $\begin{array}{r}47 \\
85 \\
- \\
48\end{array}$ & $\begin{array}{l}(3) \\
(2) \\
(-) \\
(1)\end{array}$ & $\begin{array}{c}134 \\
120 \\
- \\
273^{\star}\end{array}$ & $\begin{array}{l}(9) \\
(3) \\
(3) \\
(6)\end{array}$ \\
\hline \multicolumn{2}{|c|}{ All women I-XXV } & 90 & $(794)$ & 101 & $(411)$ & 99 & $(124)$ & 82 & (213) & 88 & $(110)$ & 72 & (41) & 87 & $(48)$ \\
\hline
\end{tabular}

SMR $=$ Standardised mortality ratio.

$\star 95^{\circ}{ }^{\circ}$ confidence interval excludes the corresponding SMR for all women classified to an occupation. 
associated with a low level of ischaemic heart disease mortality ( $S M R=15,95 \%$ CI 2-55). In general, mortality levels within this order were lower for primary and secondary school teachers (Unit 193, all cause $S M R=54,95 \%$ CI 31-88) and higher for nurses (Unit 183, all cause SMR $=80,95 \%$ CI 54-115). However mortality from circulatory diseases was equally low for both these units, and for the remainder of Order XXV.

Mortality from accidents, poisonings, and violence contrasted with this pattern of low mortality with a non-significant excess among nurses, and a significant excess among other units (excluding teachers and nurses).

An interesting feature of the mortality of nurses was a significant difference between the mortality of those working part time (SMR $=50,95 \% \mathrm{CI}$ 18-109) and those working full time $(S M R=88$, 95\% CI 55-135).

\section{ORDER XXI: CLERICAL WORKERS}

Mortality levels from each of the main cause groups were low for Order XXI. Most of the deaths in this order were associated with Units 139 (clerks and cashiers) and 141 (typists and secretaries), both of which had low all cause mortality. For these units, SMRs for the broad cause groups studied were all low, with particularly low levels for circulatory and respiratory diseases. Within the former cause group, ischaemic heart disease mortality was notably low for the order as a whole $(S M R=59$, 95\% CI 35-93) with the most marked deficit for Unit 141 (SMR $=25,95 \%$ CI 3-91). Although the overall level of cancer mortality for this order was below that of women classified to an occupation there was a slight excess of breast cancer mortality. The latter was mainly associated with Unit 139 (SMR=139, 95\% CI 93-200). After excluding Units 139 and 141, the remainder of Order XXI (primarily office machine operators) had a slightly raised level of all cause mortality (principally from cancer and circulatory diseases).

For the two main units in this order, those working full time had higher levels of mortality in 1976-81 than those working part time. Full time clerks and cashiers had significantly higher mortality (SMR $=89,95 \%$ CI 71-109) than those working part time (SMR $=58,95 \%$ CI 39-84). The mortality differential was similar, but not statistically significant, for typists and secretaries; those working full time had an SMR of $76(95 \%$ CI 52-107) and those working part time an SMR of 56 (95\% CI 29-98).

\section{ORDER XXII: SALES WORKERS}

For Order XXII, the level of cause specific mortality was similar to that of all women classified to an occupation, with the exception of cancer mortality (for which this order had a lower level). Within Order XXII, Unit 144 (shop saleswomen and assistants) had low overall mortality (SMR $=77,95 \%$ CI 59-99). This was evident for all cause groups shown except accidents, poisoning, and violence, and was particularly associated with those working part time (SMR $=65,95 \%$ CI 44-94). Among sales proprietors and managers (Unit 143) mortality from breast cancer and respiratory diseases was slightly raised. Only seven deaths were observed for the remainder of Order XXII.

ORDER XXIII: SERVICE, SPORT, AND RECREATION WORKERS

Mortality of Order XXIII was raised for all causes, malignant neoplasms, and respiratory diseases. These excesses were mainly associated with Units 164 (maids, valets, and related service workers) and 166 (charwomen, office cleaners, and window cleaners). Raised mortality from malignant neoplasms was also associated with Unit 161 (canteen assistants and counter hands). The high level for Unit 166 mainly related to lung cancer $(S M R=214,95 \%$ CI 86-440), while for Unit 164 it related as much to breast cancer as to other cancers. The excess for breast cancer in the latter unit was especially great at younger ages (the SMR for ages $15-44$ was $472,95^{\circ}{ }_{0} \mathrm{CI}$ 97-1381). While overall cancer mortality among cooks was low, they had a non-significant excess of breast cancer (SMR $=153,95 \%$ CI $31-446)$. This group also had a raised level of circulatory disease mortality, entirely as a result of a significant excess of mortality from ischaemic heart disease $(\mathrm{SMR}=360,95 \%$ CI 155-709).

\section{MORTALITY OF OCCUPATIONS OF MODERATE SIZE}

In 1976-81, the number of expected deaths exceeded 20 for only three further occupation orders (see table I). Mortality levels of the main units within these three orders are shown in table III.

Table III Mortality 1976-81 of women aged 15-59 years by occupation: orders of moderate size and their component Units. Figures in parentheses are the numbers of observed deaths.

\begin{tabular}{|c|c|c|c|}
\hline \multicolumn{4}{|c|}{ Occup } \\
\hline \multirow[t]{4}{*}{$\overline{\text { VII }}$} & $\begin{array}{l}\text { Engineering and allied trades } \\
\text { workers nec }\end{array}$ & $129^{\star}$ & (47) \\
\hline & & $\begin{array}{l}113 \\
186^{\star}\end{array}$ & $\begin{array}{l}(9) \\
(12)\end{array}$ \\
\hline & $\begin{array}{l}\text { jewellery and electrical production } \\
\text { process workers }\end{array}$ & & \\
\hline & $\begin{array}{l}\text { Other engineering and allied trades } \\
\text { workers nec }\end{array}$ & 118 & (26) \\
\hline \multirow[t]{3}{*}{ XI } & Clothing workers & 85 & (24) \\
\hline & $\begin{array}{l}\text { 76-Hand and machine sewers and } \\
\text { embroiderers, textile and light }\end{array}$ & 74 & (14) \\
\hline & Other clothing workers & 106 & (10) \\
\hline \multirow[t]{3}{*}{$\mathbf{x x}$} & Warehouse workers, storekeepers, & 113 & (38) \\
\hline & $\begin{array}{l}\text { 136-Warehouse workers, store- } \\
\text { keepers and assistants }\end{array}$ & 117 & (11) \\
\hline & $\begin{array}{l}\text { 137-Packers, labellers and related } \\
\text { workers }\end{array}$ & 112 & (27) \\
\hline
\end{tabular}

All women I-XXV $\quad 90 \quad$ (794) SMR = Standardised mortality ratio $\star 95 \%$ confidence interval excludes the

Mortality of units comprising Order XI (clothing workers) and Order XX (warehousewomen, storekeepers, packers, and bottlers) did not differ significantly from each other or from that of all women classified to an occupation. However, mortality of Order VII was significantly above that of all women classified to an occupation $\left(S M R=129,95^{\circ} \circ\right.$ CI 95-171). This excess was principally associated with Unit 54 (other metal making, working, jewellery, and electrical production process workers) whose SMR was $186(95 \%$ CI 96-325). 
Table IV Mortality 1976-81 of women aged 15-59 years in Occupation Order VII by occupation unit and cause of death. Figures in parentheses are the numbers of observed deaths.

\begin{tabular}{|c|c|c|c|c|c|c|c|c|}
\hline \multirow{2}{*}{$\begin{array}{l}\text { Cause } \\
\text { of } \\
\text { death } \\
\text { All causes } \\
\text { Malignant neoplasms }\end{array}$} & & & \multicolumn{6}{|c|}{$\begin{array}{l}\text { Order VII } \\
\text { Engineering and allied trades } \\
\text { workers nec (Units } 31-54 \text { ) }\end{array}$} \\
\hline & \multicolumn{2}{|c|}{$\begin{array}{l}\text { All women } \\
\text { with an } \\
\text { occupation }\end{array}$} & \multicolumn{2}{|l|}{ All } & \multicolumn{2}{|c|}{$\begin{array}{l}\text { Unit } 54 \\
\text { Other metal } \\
\text { workers etc }\end{array}$} & \multicolumn{2}{|c|}{$\begin{array}{l}\text { Rest of } \\
\text { Order VII }\end{array}$} \\
\hline $\begin{array}{l}\text { All causes } \\
\text { Malignant neoplasms } \\
\text { Circulatory diseases } \\
\text { Respiratory diseases } \\
\text { Accidents, poisonings, }\end{array}$ & $\begin{array}{r}90 \\
101 \\
82 \\
72 \\
87\end{array}$ & $\begin{array}{r}(794) \\
(411) \\
(213) \\
(41) \\
(48)\end{array}$ & $\begin{array}{l}129^{\star} \\
153 \\
145^{\star} \\
87 \\
48\end{array}$ & $\begin{array}{r}(47) \\
(26) \\
(16) \\
(2) \\
(1)\end{array}$ & $\begin{array}{l}186^{\star} \\
300^{\star} \\
105 \\
- \\
255\end{array}$ & $\begin{array}{r}(12) \\
(9) \\
(2) \\
(0) \\
(1)\end{array}$ & $\begin{array}{l}117 \\
121 \\
154^{\star} \\
105 \\
-\end{array}$ & $\begin{array}{r}(35) \\
(17) \\
(14) \\
(2) \\
(0)\end{array}$ \\
\hline
\end{tabular}

and violence

${ }^{\star 95} \%$ confidence interval excludes the corresponding cause-specific SMR for all women with an occupation excess just failed to achieve statistical significance. Future work, based on a longer period of follow up, will help overcome this limitation. In addition the Longitudinal Study provides scope to take into account extrinsic factors, such as the socioeconomic and geographical distributions of particular occupations.

The phrasing of the census question in 1971 was such that women classified to an occupation were predominantly those in employment in the week before the census, and were consequently affected by the healthy worker effect. ${ }^{20}$ Furthermore we do not know how long women for whom we had occupational information were in the same job prior to 1971, while for housewives we had no information on previous occupation. The characteristics described here relate to 1971 and yet we have analysed mortality in the following decade when these may well have changed.

Among those classified to an occupation, further problems are encountered as a result of the concentration, in only a few occupations, of jobs done by women, ${ }^{21}$ as well as the failure of the Registrar General's Occupational Classification (designed primarily for use with male occupations) to differentiate adequately between these jobs. ${ }^{22}$ Furthermore, largely as a result of their domestic responsibilities, women's employment patterns are very different from those of men. Women are more likely to have interrupted careers in the labour market, frequently work part time, and have jobs which do not reflect their training or skills.

Despite these problems this analysis shows some interesting results. There are occupational mortality differentials which broadly conform to social class differentials which earlier work has led us to expect. ${ }^{23}$ Order VII (engineering and allied trades workers) stands out as having particularly high mortality in 1976-81; it predominantly comprised manual workers in Social Class IIIM and IV. This order, and in particular Unit 54, had exceedingly high cancer mortality throughout the decade, although there was no strong evidence to suggest that any particular cancer site was of special importance. In the 1971 national cross sectional data, ${ }^{6}$ the proportional mortality ratio for lung cancer was high for Order VII and for Unit 39 (one of the main constituent units) while that for stomach cancer was particularly high. In the corresponding 1981 data, ${ }^{24}$ excesses were evident for lung cancer among Units 39 and 54, as well as for uterine cancer in Unit 54 . In the Longitudinal Study in 1976-81, circulatory disease mortality levels were high in the remainder of the order, having excluded Unit 54; the excesses were most marked for cerebrovascular disease. In the 1981 cross sectional data, Unit 39 had high circulatory disease mortality and both Units 39 and 54 had raised mortality from ischaemic heart disease. In the Longitudinal Study, throughout Order VII, mortality from respiratory diseases declined over the decade from a very high level in 1971-75. It has been suggested (in relation to men) ${ }^{6}$ that some component units of Order VII attract workers with poor health, or disabilities ${ }^{25}$ and in turn, the conditions of employment may aggravate their illness or bring about further disease. The 
number of deaths available for analysis here does not permit further investigation of this hypothesis which relates primarily to rare causes of death.

Order XXIII (service, sport and recreation workers), also had raised mortality, although just failing to differ significantly from that of all women with an occupation. This order consisted mostly of manual workers, suggesting that their raised mortality was, in part, a social class effect.

Probably the most notable finding (and one that cannot be entirely explained by social class distribution) was the exceptionally high ischaemic heart disease mortality of Unit 162 (cooks). There is strong evidence that this $1976-81$ level represented an increase on that earlier in the decade. An association is aetiologically plausible, and was also reported in the 1981 Decennial Supplement. Our data suggest that cooks also have raised breast cancer mortality.

Unit 166 (charwomen and cleaners) had high mortality from all malignant neoplasms in 197681 , largely accounted for by an excess in lung cancer mortality which exceeded that observed in 1971-75. This finding of raised lung cancer mortality mirrors cross sectional data from both the 1971 and 1981 censuses. The Longitudinal Study also suggests an increased level of respiratory disease mortality throughout the decade. In cross sectional data this was confined to a suggestion of raised mortality from this cause among older women in $1971 . .^{11}$ It may be that, among younger women, cross sectional data are distorted by a tendency for occupation to be particularly poorly reported when death results from chronic disease (such as bronchitis). While raised levels of lung cancer and respiratory disease mortality may be explained by the high levels of smoking among manual workers, it is possible that the effects of cigarette smoking were compounded by carcinogens and irritants ${ }^{26}$ to which many cleaners are exposed.

The remainder of Occupation Order XXIII, having excluded the above two units, had raised cancer mortality in 1976-81. This was principally associated with Unit 164 (maids), who had raised mortality from breast cancer.

The other occupation orders containing large numbers of women had low levels of all cause mortality. This may well reflect their class composition. Order XXV (professional, technical workers, and artists) consisted entirely of women in Social Class II, mainly teachers and nurses, while all those in Order XXI (clerical workers) were in Social Class III N. Despite the low all cause mortality of these orders, several cause specific findings are of interest, especially in relation to their constituent occupation units.

Clerks and cashiers (Unit 139) had high breast cancer mortality in 1976-81, a clear increase over the level earlier in the decade. This finding is supported by cross sectional data for both 1971 and 1981 and is consistent with hypotheses linking mortality from breast cancer to higher social status. ${ }^{27}$ Roman $e t$ al found a relative excess of breast and other reproductive cancers among professional and clerical workers which they concluded probably reflected the high proportion of nulliparous women in these groups. ${ }^{10}$

The remainder of Order XXI, having excluded units 139 and 141, had high levels of cancer mortality throughout the decade and of circulatory disease mortality in 1976-81. This group consisted mainly of office machine operators, but also included civil service executive officers; in the 1971 cross sectional data, the latter group had raised proportional mortality ratios among older women from all cancers, in particular those of the buccal cavity, pharynx, and ovary.

After excluding teachers and nurses, the remainder of Occupation order XXV experienced very high mortality from accidents, poisonings, and violence throughout the decade. The 1971 Decennial Supplement cited nurses, medical practitioners, teachers, and authors as having raised proportional mortality ratios from this cause group, mentioning an excess of suicide deaths in each instance.

In view of the small numbers of deaths currently available for analysis, the scope for analysing occupation by hours worked was clearly limited; even so this analysis pointed to some interesting findings. Women working part time as clerks and cashiers, typists and secretaries, or nurses, had exceptionally low mortality (SMRs below 60 ) in 1976-81, considerably lower than the (already quite low) mortality of those working full time. Part time workers are predominantly married women with children and consequently two groups known to have raised mortality are excluded, namely the single, ${ }^{23}$ and the nulliparous. ${ }^{28}$ However this selection argument is only one of several possible explanations for the differential mortality of full time and part time workers. ${ }^{29}$ Our previous work ${ }^{29}$ showed that among married women the difference in mortality of those in full and part time work was greater for women in non-manual than manual social classes. This was true irrespective of whether the woman had a dependent child or not.

\section{Conclusions}

This work has identified some interesting and important findings relating to women's occupational mortality. Among women in paid employment there are differences in all cause mortality according to occupation and, in addition, some associations between cause of death and occupation were identified.

However characterising women's lives by their occupation alone is of limited value in view of their position in the labour force. Women move in and out of paid employment according to their domestic responsibilities, frequently taking jobs which fit in with caring for children, elderly relatives, husbands, and homes. Hence jobs often do not reflect the woman's skills, training, or full potential. Women have interrupted careers in the job market, often working part time, sometimes working as homeworkers. This pattern is in marked contrast to that of men who, until recently, tended to be in paid employment throughout their working lives, often in the same or similar work.

Whether a woman is a housewife or in paid employment, as well as the type of job she does and whether it is full or part time, will depend on a range of factors including her marital status, parity, and domestic responsibilities. These aspects of a woman's life, in addition to her 
husband's social class (if married), and household wealth, cannot be ignored. The Longitudinal Study enables us to incorporate these dimensions in our analyses. ${ }^{30}$ The analyses reported in this paper could be extended by making use of a composite index of work position developed by colleagues at City University ${ }^{31}$ and by using information from both the 1971 and 1981 censuses to derive work histories. ${ }^{32}$ In addition as the length of follow up increases results from the study will become more firmly based.

\section{Crown copyright is reserved}

1 Wignall BK, Fox AJ. Mortality of female gas mask assemblers. $\mathrm{Br}$ F Ind $\mathrm{Med}$ 1982; 39: 34-8.

2 Newhouse ML, Berry G, Wagner JC, Turok ME. A study of the mortality of female asbestos workers. $\mathrm{Br} \mathcal{F}$ Ind Med 1972; 29: 134-41.

3 Fox AJ, Collier PF. Mortality experience of workers exposed to vinyl chloride monomer in the manufacture of polyvinyl chloride in Great Britain. Br $\mathcal{F}$ Ind Med 1977; 34: 1-10.

4 Berry G, Molyneux MKB, Tombleson JBL. Relationships between dust level and byssinosis and bronchitis in Lancashire cotton mills. $\mathrm{Br} \mathcal{F}$ Ind Med 1974; 31: 18-27.

5 Registrar General. Decennial supplement: England and Wales 1931, part IIa. London: HMSO, 1938.

6 Registrar General. Occupational mortality 1970-72. Decennial supplement. (Series DS No. 1) London: HMSO, 1978.

7 MacFarlane A. Official statistics and women's health and illness. Equal Opportunities Commission, Research Bulletin No 4, 1980: 43-77.

8 Moser KA, Goldblatt PO. Mortality of women in the OPCS Longitudinal Study; differentials by own occupation and household and housing characteristics. (Social Statistics Research Unit Working Paper No 26). London: City Research Unit Wor.

9 Moser KA, Pugh HS, Goldblatt PO. Inequalities in women's health: developing an alternative approach. (Social Statistics Research Unit Working Paper No 54). London: City University, 1987.

10 Roman E, Beral V, Inskip H. Occupational mortality among women in England and Wales. $B M F$ 1985; 291: $194-6$.

11 Registrar General. OPCS Monitor (Reference DHI 85/1) Women's occupational mortality, 1970-72. London HMSO, 1985.

12 Alderson $M$. Cancer mortality in male hairdressers. $f$ Epidemiol Community Health 1981; 36: 69-80.
13 Fraser P, Chilvers C, Goldblatt P. Census based mortality study of fertiliser manufacturers. $B r \mathcal{F}$ Ind Med 1982; 39: 323-9.

14 Harrington JM, Goldblatt PO. Census based mortality study of pharmaceutical industry workers. $\mathrm{Br}$ F Ind Med 1986; 43: 206-11.

15 Fox AJ, Goldblatt PO. Socio-demographic mortality differentials: longitudinal study 1971-75 (Series LS No 1). London: HMSO, 1982

16 Registrar General. Classification of occupations 1970. London: HMSO, 1970

17 Martin J, Roberts C. Women and employment: a lifetime perspective. London: HMSO, 1984.

18 Fox AJ, Goldblatt PO, Jones DR. Social class mortality differentials: artefact, selection or life circumstances? $\mathcal{f}$ Epidemiol Community Health 1985; 39: 1-8.

19 Fox AJ, Goldblatt PO, Adelstein AM. Selection and mortality differentials. I Epidemiol Community Health 1982; 36: 69-79.

20 Fox AJ, Collier PF. Low mortality rates in industrial cohort studies due to selection for work and survival in the industry $\mathrm{Br}$ F Prev Soc Med 1976; 30: 225-30.

21 Hakim C. Occupational segregation. Department of Employment Research Paper No 9. London: HMSO, 1979.

$22 \mathrm{McDowall} M$. Measuring women's occupational mortality. Population Trends 1983; 34: 25-9.

23 Moser KA, Pugh HS, Goldblatt PO. Inequalities in women's health: looking at mortality differentials using an alternative approach. BMF 1988; 296: 1221-4.

24 Registrar General. Occupational mortality 1979-80, 198283. Decennial supplement. London: HMSO, 1986.

25 Ostlin P. Negative health selection into physically light occupations. F Epidemiol Community Health 1988; 42: $152-6$.

26 Doll R, Gray R, Hafner B, Peto R. Mortality in relation to smoking: 22 years' observations on female British doctors. BMF 1980; i: 967-71.

27 Leon D. Social distribution of cancer: longitudinal study 1971-75 (Series LS No 3). London: HMSO, 1988.

28 Green A, Beral V, Moser K. Mortality in women in relation to their childbearing history, $B M F$ 1988; 297: 391-5.

29 Moser KA, Pugh HS, Goldblatt PO. Inequalities in women's health in England and Wales: mortality among married wealth in England and Wales: mortality among married characteristics and life-cycle stage London: Genus, 1991 (in press).

30 Pugh HS, Moser KA. Measuring women's mortality differences. In: Roberts $\mathrm{H}$, ed. Women's health counts. London: Routledge, 1990.

31 Roberts H, Barker R. The social classification of women's work. User guide to the OPCS Longitudinal Study (Social Statistics Research Unit Working Paper No 46). London: City University, 1990.

32 Dex S. Women's occupational mobility: a lifetime perspective. London: Macmillan, 1987. 